(C) The Author(s), 2021. Published by Cambridge University Press on behalf of the Arizona Board of Regents on behalf of the University of Arizona. This is an Open Access article, distributed under the terms of the Creative Commons Attribution-NonCommercial-ShareAlike licence (http:// creativecommons.org/licenses/by-nc-sa/4.0/), which permits non-commercial re-use, distribution, and reproduction in any medium, provided the same Creative Commons licence is included and the original work is properly cited. The written permission of Cambridge University Press must be obtained for commercial re-use.

\title{
TREE-RING-RADIOCARBON DATING AT A LATE CONTACT PERIOD KITKAHAHKI PAWNEE SITE ON THE CENTRAL GREAT PLAINS, USA
}

\author{
Nicholas V Kessler ${ }^{*}$ (D) $\bullet$ Gregory W L Hodgins ${ }^{2} \cdot$ Michael C Stambaugh $^{3} \cdot$ Mary J Adair $^{4}$ \\ ${ }^{1}$ Laboratory of Tree-Ring Research, University of Arizona, 1215 E. Lowell St., Tucson, AZ 85721, USA \\ ${ }^{2}$ Accelerator Mass Spectrometry Laboratory, University of Arizona, 1118 E. Fourth St., PO Box 210081, Tucson, AZ \\ 85721-0081, USA \\ ${ }^{3}$ Missouri Tree-Ring Laboratory, University of Missouri, 203C ABNR Bldg., Columbia, MO 65211, USA \\ ${ }^{4}$ Archaeology Division, Biodiversity Institute, University of Kansas, Spooner Hall, 1340 Jayhawk Blvd., Lawrence, KS \\ 66045 , USA
}

\begin{abstract}
This study obtained calendar dates by radiocarbon accelerator mass spectrometry $\left({ }^{14} \mathrm{C}\right.$ AMS) dating sequential tree-rings of wooden support posts from the buried remains of traditional Kitkahahki Pawnee earthlodges preserved at an archaeological site on the Central Great Plains, USA. The tree-ring segments from the site were dendrochronologically analyzed prior to this study, but the cross-matched site chronology could not be definitively cross-dated and was thus "floating" in time. Our study represents the first floating tree-ring chronology from the Great Plains to be anchored in time by means of independent radiocarbon analysis. Three specimens were analyzed and dated to 1724-1774 CE (82.0\% probability), 1774-1794 CE (95.4\% probability), and 1800-1820 CE $(95.4 \%$ probability). These dates correspond to the hypothetical timing of Kitkahahki ethnogensis, the main phase of village growth in the area, and a later reoccupation during a turbulent period in regional history. The results of this study conform to a scenario in which chaotic social conditions correspond to an increase in residential mobility between the core of Pawnee territory and a southern frontier in the Republican River valley.
\end{abstract}

KEYWORDS: AMS dating, dendrochronology, historic period, Pawnee.

\section{INTRODUCTION}

Intercultural contact, conflict, and participation in interregional networks caused profound social and demographic changes for Pawnee (Chaticks-si-Chaticks) society on the Great Plains of North America during the Contact Period from the 18th through 19th centuries CE (all dates CE). Like many Indigenous communities during this time, the Pawnee resisted colonization and genocide; participated in global economic systems as producers, consumers, and middlemen; expanded and contracted their territory; and withstood sociopolitical instability (Wishart 1979; White 1988; Kinbacher 2012; Steinke 2012; van de Logt 2016). Within this context, Pawnee society transformed: intensifying production of trade commodities, aggregating into fortified villages, expanding and contracting residential and hunting territories, and altering ways of signaling sociopolitical status (Wedel 1936; Echo-Hawk 1992; Roper 2006; Callahan-Mills 2012; Echo-Hawk 2018; Beck 2020). However, an objective record of Pawnee movement and cultural change is severely hampered by the lack of a scientific chronology. Settlement histories outside of the core area of the Pawnee homeland, in eastern and central Nebraska, remain uncertain as they are based mainly on European documents and artifact assemblages (Adair et al. 2008). This is problematic because recent studies have demonstrated that culture histories inherited from documentary sources or the presence and absence of trade goods can contain significant errors, and specialists have argued convincingly for the application of

\footnotetext{
*Corresponding author. Email: nvkessler@email.arizona.edu.
} 


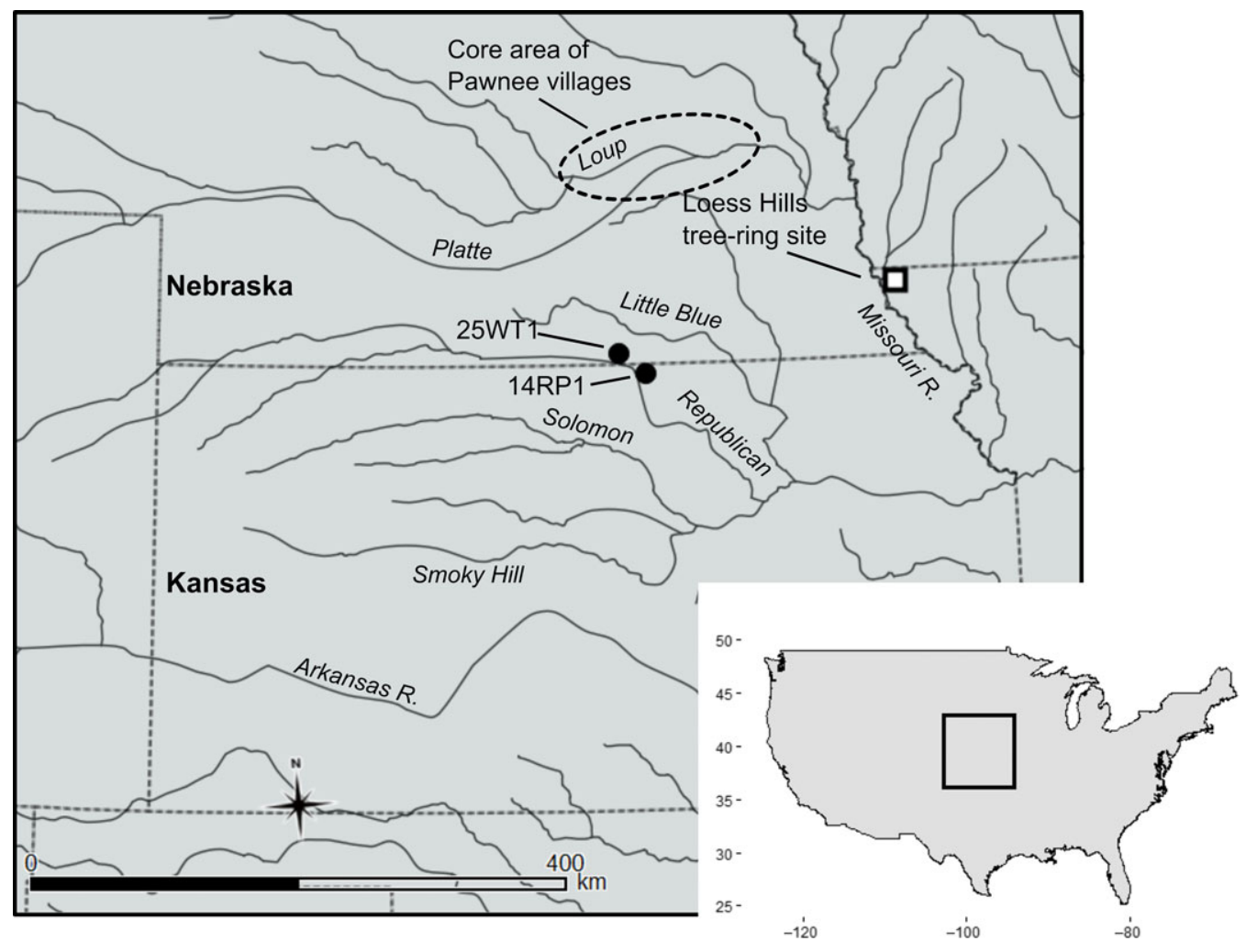

Figure 1 Overview of the Central Great Plains region and the locations of the two Pawnee archaeological sites and the tree-ring chronology site mentioned in the text. The core area of Pawnee villages refers to the main focus of Pawnee settlement from the 16th through 19th centuries.

independent dating at Contact Period archaeological sites (for example Manning et al. 2018; Manning and Hart 2019). Fortunately, acknowledgement of the inadequacies of inherited culture history frameworks has driven advances in chronometric research at Contact Period sites.

This paper describes a tree-ring radiocarbon (wiggle-matching) dating effort at the Kansas Monument site (14RP1), an earthlodge village that was one of multiple residences established by the Kitkahahki band of the Pawnee along the Republican River (Figure 1). This study follows a research project that began in 2007 with three goals: analyzing an extensive artifact collection from earlier investigations, evaluating the relationship among the 11 excavated lodges and fortification trench, and determining the time of site occupation (Adair et al. 2008). The latter goal was initially addressed by the analysis of historic European trade items, Pawnee oral tradition, and Pawnee ethnohistory. Dendrochronology was attempted to establish calendar ages for the beams used in the construction of earthlodges at 14RP1 and the nearby Hill Farm site (25WT1). This effort succeeded in constructing a floating site chronology for 14RP1, but the lack of correlation to any master dating series prohibited assigning absolute calendar dates to the ring segments (Stambaugh n.d.). 
The present study sought to obtain calendar dates by accelerator mass spectrometry (AMS) dating sequential tree rings from three specimens previously subjected to dendrochronological study. Our objective was to independently evaluate the general time span for site occupation and to test a hypothesis that the occupation of 14RP1 was characterized by multiple distinct phases of lodge construction as suggested by historical information. While dendrochronological analysis alone could not definitively date ring segments from the analyzed specimens, sequential AMS dates on the cross-matched ring series did produce high precision calendar ages, supporting a specific chronological placement for two lodges at 14RP1. This study demonstrates the utility of wiggle-matching tree-ring segments on the Great Plains and takes initial steps toward using the technique to building longer local tree-ring chronologies. Our results support previously proposed start dates for Kitkahahki Pawnee occupation in north-central Kansas beginning in the middle to latter half of the 18th century, provide evidence for lodge construction into the 19th century, and provisionally supports a historical scenario of repeat occupation during a particularly tumultuous time period in Kitkahahki history.

\section{Kitkahahki History}

The Pawnee are a Caddoan speaking group classified into four extended bands-Skiri, Chawi, Kitkahahki, and Piittahawiraata - whose territory extended across much of the Central Great Plains of Nebraska and northern Kansas (Wedel 1936). Traditionally, the Pawnee practiced a self-sufficient agricultural, hunting, and craft economy in which people lived in agricultural villages for part of the year and utilized seasonal camps associated with specific resources (Wedel 1936; Weltfish 1965). Crops were raised in village gardens and bison were hunted in two extra-local communal affairs during the summer and winter. The Pawnee, like other Plains Villagers, lived in circular earthlodges while residing in the village. Earthlodges are substantial timber-framed soil-covered dwellings that usually housed an extended matrilocal household (Roper and Pauls 2005). Early Spanish chronicles, date formulas based on ceramic style, and a small number of radiocarbon $\left({ }^{14} \mathrm{C}\right)$ dates from archaeological sites in Nebraska suggest that Pawnee were living in the lower Loup River valley by the 1500 s (Grange 1984). Archaeologists identify the Pawnee as one of multiple ethnolinguistic groups decedent from a generalized Plains Village cultural tradition, with sites distributed across the Central Plains since the 900s CE (Johnson 1998).

Archaeological evidence shows that Pawnee life began changing significantly as involvement with Europeans increased in the 18th century. The Spanish Colonial government sent military and diplomatic missions to the Central Plains while the French established persistent trading relations with the Pawnee in what is now eastern Nebraska (Hyde 1988). Over the course of the 18th century, metal tools and other trade goods of European and American manufacture increased in prevalence in a variety of contexts and collectively suggest that Pawnee were investing heavily in the bison robe trade (Beck 2020). Though the timing is unclear, Pawnee intensified bison hunting activities on the High Plains sometime after the 1600s leading to the development of the historically documented summer-winter communal hunts (Roper 1992). Changes in burial goods to include more metal and glass items after the middle 1700s suggests that ways of signaling prosperity in Loup and Platte River Pawnee communities were shifting to displays of traded commodities (Callahan-Mims 2012). At the same time, archaeologists record major shifts in ceramic vessel and lithic tool manufacture in the Pawnee core area, hypothesized to result from the socioeconomic consequences of intensified bison hunting and processing (Beck 2020; Hudson 1993). Archaeological survey 
data show a clear trend toward aggregation, or higher population densities in larger fortified villages, correlated with increased volumes of metal and glass goods across Pawnee settlements from the middle 1700s to 1850s (Wedel 1936). According to the survey descriptions reported by Wedel (1936), Pawnee villages founded in the 1770s averaged around 7 ha in area, villages founded in the first three decades of the 1800s averaged slightly more than 10 ha in area, while those founded after 1840 averaged more than 15 ha in area.

It is not known precisely when the Kitkahahki established villages in the Republican River valley. Documentary evidence suggests that the first Kitkahahki villages may have been established sometime after 1758 and before 1777 with intermittent occupation for about 10-30 years after 1800. It is unclear exactly how 14RP1 fits into this general timeline, but documents and archaeological evidence strongly indicate occupation for this site in the 1790s, while conjectural evidence could indicate occupations from around 1805-1810 and the 1820s. A map produced by the Marquette and Jolliet expedition up the Missouri River in 1673 accurately placed Pawnee villages near the junction of the Platte and Loup Rivers, but not farther south (Wedel 1936: 11). A report by a Spanish colonial official identifies the Kitkhahki ("La Republica" as the group was known at the time) living along the Republican River by 1777 (Houck 1909: 143), but excerpts from earlier French documents make no reference to Kitkahahki or any Pawnee in the Republican valley in 1758 (Nasatir 1952: 52). Villages definitively appear along the Republican River on a Spanish map drawn in 1795 (Wood 1996: Figure 4), and trade routes are depicted linking Pawnee villages on the Republican to locations in modern day southeastern Nebraska (p. 196). Lewis and Clark did not record Kitkahahki in the Republican valley in 1804 because they had recently moved to join settlements on the Loup River (Wedel 1936: 17). The site 25WT1 was certainly [re]occupied in 1806 because it was the location of Zebulon Pike's meeting with Kitkahahki leaders on the first American expedition to the Rocky Mountains in 1806 (Munday 1927). Multiple American military and missionary sources report Kitkahahki living at different locations along the Loup River from 1811 through the 1830s, and their absence from the Republican valley is conspicuous (Wedel 1936: 17-18). Based on this information and analysis of ceramic assemblages, the date 1811 is commonly assigned as the end point of occupation at 25WT1 with a hiatus from 1800 or 1802-1806 (Grange 1984). Based in part on the omission from the Pike Expedition chronicles, and on speculation that 14RP1 was more vulnerable to attack by neighboring groups, 14RP1 is assumed to have been depopulated around 1800-1802 and not reoccupied (Wedel 1936: 33). The absence of English gunflints at 14RP1, a loose chronological indicator, appears to confirm that 14RP1 was not occupied for many years beyond 1800 (Asher 2009).

However, there are indications of a later reoccupation which contradict the above scenario. Jedediah Smith-an American hunter and explorer-may have stayed briefly with Kitkahahki in the Republican valley during the summer of 1826 based on journals and receipts for supplies his party consumed during this visit (Gunnerson and Gunnerson 1988 citing Barry 1972). Based on oral history and trade documents, scholars suggest that this later occupation began in 1823 (Adair et al. 2007). The stories contained in the work of Echo-Hawk (2018) parallel this narrative; wherein he postulates a small-scale re-occupation of the Republican valley in the 1820 s by refugees of epidemics in the larger Loup River villages. The chronology of this story coincides generally with a documented smallpox epidemic among the Pawnee along the Platte and Loup occurring in 1824-1825 (Vehik 1989). The convergence of this information is intriguing and could suggest a scenario in which groups of Kitkhahki splintered from the main Pawnee settlements in the Loup to 
establish and reoccupy villages in the Republican valley for a variety of reasons. While somewhat speculative, it is clear from this overview that gaps and contradictions in historical documents and material culture result in major uncertainty in Kitkahahki history and Pawnee sociopolitical change more broadly. This research is an attempt to begin addressing these data deficiencies.

\section{${ }^{14}$ C-Based Cultural Chronologies on the Central Great Plains}

Growing databases of AMS dates on short-lived annual plants and food residues have advanced the general time frames for cultural phases and key transitions in late preContact Plains history. Recent work combining ceramic stylistic analysis and AMS dating of food residue on pots has narrowed the age range for Hopewell communities-dated to between $100 \mathrm{BC}$ and $400 \mathrm{AD}$-in the vicinity of present-day Kansas City, Missouri (Keehner and Adair 2019). Previously, Roper (2012; Roper and Adair 2011) tightened the age ranges of agricultural villages in Kansas and Nebraska-dating to between 900 AD to $1420 \mathrm{AD}$ - through the critical assessment of legacy radiocarbon datasets and new AMS determinations. Chronological research on the High Plains of Kansas, Nebraska, and Colorado has reevaluated the consistency of archaeological trait-list approaches for identifying ethnolinguistic groups (in this case Plains Apache) in the archaeological record (Hill and Trabert 2018).

For these studies, calibrated age ranges of radiocarbon dates can span several decades to centuries. Ninety-five percent probability ranges span an average of 142 years in the period from ca. $360 \mathrm{BC}$ to $670 \mathrm{AD}$ (Keehner and Adair 2019, Table 5); 108 years in the period from ca. 900 AD to 1460 AD (Roper 2012: Table 1; Roper and Adair 2011: Table 3); and 209 years after ca. 1500 AD (Hill and Trabert 2018, Table 1). Elsewhere, Bayesian calibration of multiple sequential dates has allowed archaeologists to refine the precision of cultural chronologies and date the initiation, cessation, and rate of past events (Bayliss 2009; Bayliss et al. 2007). However, because of the rarity of deeply stratified cultural deposits at late pre-Contact and Contact Period sites on the Central Plains, Bayesian sequence models from individual sites have had less impact on chronology building in this region. Without empirical evidence for temporal/stratigraphic ordering, it is tempting to rely on historical documents or culture historical frameworks to specify Bayesian priors, but this risks imposing tautologies on site chronology and can undermine independent dating (Bronk Ramsey 2000). One avenue for improving the precision of ${ }^{14} \mathrm{C}$-based chronologies on the Great Plains could be through the systematic application of wigglematch calibration of ${ }^{14} \mathrm{C}$ measurements on tree rings from contexts were sufficient wood is preserved.

Wiggle-matching refers to the form of Bayesian ${ }^{14} \mathrm{C}$ age calibration wherein model priors include not only the temporal order of the dated materials (tree rings), but also the precise time gap between them (Bronk Ramsey et al. 2001). This technique matches sequential ${ }^{14} \mathrm{C}$ variability archived in a segment of annual tree-rings to variability in historic atmospheric ${ }^{14} \mathrm{C}$ content, and is the most efficient way to achieve independent high precision calendar dates in contexts where suitable samples are available but traditional dendrochronological cross-dating fails (Galimberti et al. 2004). Wiggle-match calibration of sequential tree rings can provide independent, high resolution dates, that in some contexts, can help overcome some of the limitations of age models based only on short lived material. Recent studies show how the inclusion of only a few wiggle-matched dates in Bayesian sequences from 
Table 1 Description of ${ }^{14} \mathrm{C}$ samples obtained by this study from earth lodge support posts at 14RP1.

\begin{tabular}{|c|c|c|c|c|}
\hline Sample ID & Context & $\begin{array}{l}\text { Sampled rings, numbered } \\
\text { from pith (pith=0) }\end{array}$ & $\begin{array}{l}\text { Relative year in floating } \\
\text { chronology (first measured } \\
\text { ring in chronology = year } 1 \text { ) }\end{array}$ & Lab ID \\
\hline H-1-2-A & House 1 , & 1 & NA & AA112013 \\
\hline H-1-2-B & post 2 & 37 & NA & AA 112014 \\
\hline $\mathrm{H}-1-2-\mathrm{C}$ & & 82 and 83 & NA & AA112015 \\
\hline H-1-4-A & House 1 , & 1 & 1 & AA112016 \\
\hline H-1-4-B & post 4 & 23 & 23 & AA 112017 \\
\hline $\mathrm{H}-1-4-\mathrm{C}$ & & 34 and 35 & 34.5 & AA112018 \\
\hline H-4-1-A & House 4, & 2 & 31 & AA112019 \\
\hline H-4-1-B & post 1 & 22 & 51 & AA 112020 \\
\hline H-4-1-C & & 33 & 62 & AA112021 \\
\hline
\end{tabular}

short-duration contexts can significantly improve the resolution of date models in calibration plateaus and reversals (Manning et al. 2020). Wiggle-match dating has been used with increasing frequency to obtain independent calendar dates for ancient and historical structures (Nishimoto et al. 2010; Hogg et al. 2017; Marshall et al. 2019), shipwrecks (Lorentzen et al. 2014), artifacts (Park et al. 2010; Kim et al. 2013; Manning et al. 2014; Fukuyo et al. 2019), and to anchor floating tree-ring chronologies (Hogg et al. 2002; Manning et al. 2010; Pearson et al. 2014; Kim et al. 2015; Panyushkina et al. 2017; Turkon et al. 2018).

\section{METHODS AND MATERIALS}

\section{Study Site and Sampling}

The study site consists of a fortified village with evidence for at least 30 lodges (Roper 2006). Specimens analyzed in this study were wooden building posts recovered as charred and rotted stubs from post molds below the floors of Houses 1 and 4 (Figure 2). The posts were excavated by the University of Kansas in 1949 (House 1), and the Kansas State Historical Society in four field seasons from 1965 through 1968 (House 4) (Smith 1949; Witty and Jones 1966; Roberts 1978). Bur oak (Quercus macrocarpa) was overwhelmingly preferred for central support posts for lodges at 14RP1, and all the samples analyzed in the study are of this species (Kessler 2009). Samples in this study are designated by a number identifying the lodge, followed by a dash and a number assigned by excavators identifying the post, followed by a letter identifying the ring or rings in their respective sequence (starting with " $\mathrm{A}$ " for the innermost ring). Due to the taphonomic condition of the specimens-in which the final growth ring and all sap wood has been eroded-all dates represent the terminus post quem, or the time after which the trees were felled.

\section{Tree-Ring Dating}

A total of 11 bur oak posts were transported to the Missouri Tree-Ring Laboratory at the University of Missouri, Columbia, for dendrochronological analysis. Samples were cut at 


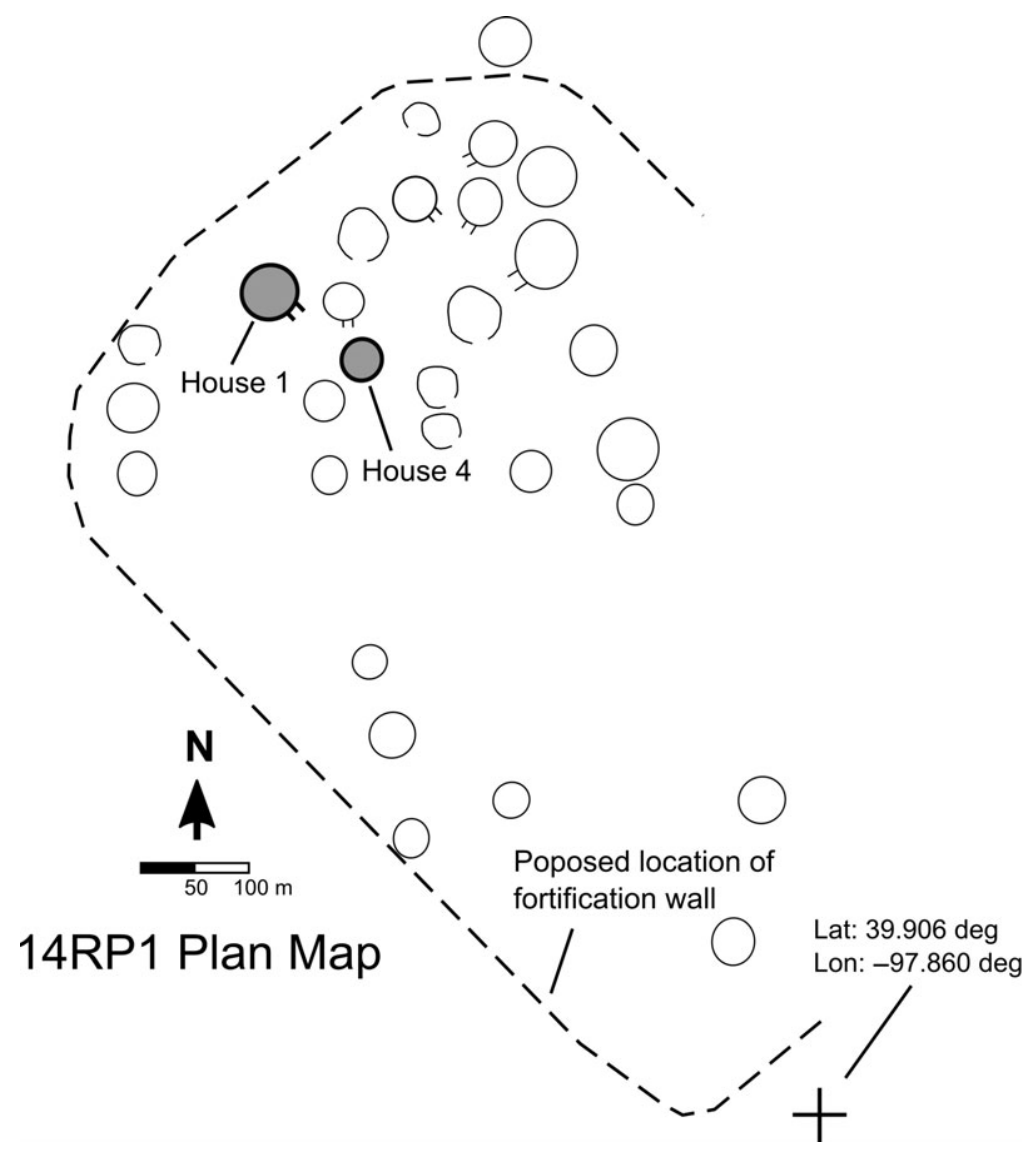

Figure 2 Plan map of 14RP1 showing the locations of House 1 and 4 (shaded circles) from which the three ${ }^{14} \mathrm{C}$ dated specimens were excavated previously. Map is based on the sketch map of Carlyle Smith published by Adair et al. (2007) and geo-rectified from satellite imagery.

their widest points using a band saw and surfaces were sanded with progressively finer grit until ring anatomy was plainly visible under $40 \times$ magnification. Tree-ring widths along two radii of each cross-section were measured to $0.01 \mathrm{~mm}$ precision using an electronic transducer fixed to a moving stage. Ring-width graphs were compared on a light table for the purposes of pattern matching and to check for outlier measurements. Additional checks were made by comparing anatomical wood features that might be regional chronological markers of severe early growing season frost damage including lunate (moon) shaped earlywood vessels, earlywood vessels offset from ring boundaries, and callus tissue (following Stahle 1990).

Ring sequences from 14RP1 were compared to multiple master dating chronologies from bur oak and post oak (Quercus stellate) in the region (Stambaugh et al. 2006; Stambaugh and Guyette 2009). Cross-dating was verified statistically with the COFECHA computer program. COFECHA is used to check the accuracy of cross-dating using correlation analysis, t-tests, and outlier identification (Holmes 1983). Once samples were cross-dated, a master dating chronology was developed using established dendrochronological techniques for producing standardized master chronologies (Cook et al. 1990). This was accomplished 
using the ARSTAN computer program (Cook et al. 1986) as well as the dplR package (Bunn et al. 2017) in the statistical computing program $R$ (R Core Team 2019). Mean chronologies were computed by removing the biological age-growth trend to produce an index of ring widths with a mean of 1.0, where deviations from the mean represent changes in growth limiting conditions, often a growing season drought signal.

\section{Radiocarbon Dating}

Select lodge posts were submitted for radiocarbon dating with three specimens yielding a total of nine ${ }^{14} \mathrm{C}$ samples (Table 1). As detailed in the next section, two specimens (H-1-4 and H-4-1) were cross-matched dendrochronologically and together spanned the entirety of the floating site chronology. These two specimens contained 33 and 34 rings respectively. A third specimen (H-1-2), could not be cross-matched in the site chronology. This sample was selected because it contained 83 rings, the highest ring count in the collection of posts available for analysis from the site.

Specimens were sampled for radiocarbon measurements at the Division of Archaeology, Biodiversity Institute, University of Kansas, Lawrence. Rings in each cross-section were counted, and the ring counts checked against the measured ring series. Individual rings were dissected from each specimen from the innermost (designated "A"), middle (designated "B"), and outermost (designated "C") portions of the ring sequence. In some cases, two or three rings were sampled and pooled where narrow ring widths dictated taking multiple rings to obtain sufficient sample weights. For pooled samples the ring count mid-point was used as the dating point.

Preserving buried wood from archaeological sites with a mixture of paraffin and gasoline was a common treatment in the times in which 14RP1 was excavated. While the specimens had no outward signs of such treatment, they were all pretreated with hexane-acetone-alcohol-water rinses that would remove any possible hydrocarbon contamination. Samples were soaked in hexane for 24 hours, decanted and rinsed in acetone, followed by rinses in ethanol, methanol, and deionized water. This was followed by acid-base-acid treatment designed to remove inorganic carbon and humates. The samples were then rinsed in deionized water until a neutral $\mathrm{pH}$ was obtained. Lignins were extracted using an acetic acid hypochlorite solution, and the samples were then treated with $17 \% \mathrm{NaOH}$ to produce alpha cellulose. A fraction of the alpha cellulose of each sample was combusted on a vacuum line to obtain purified $\mathrm{CO}_{2}$ gas. Radiocarbon dates were calibrated against IntCal20 (Reimer et al. 2020) in wiggle-match (D_sequence) models in the OxCal 4.3 online calibration program (Bronk Ramsey 2009).

\section{RESULTS}

\section{Tree-Ring Dating}

Cross-matching ring series from five specimens, representing five different trees, produced a floating chronology spanning a total of 62 years. The mean interseries correlation among ring-series in the floating chronology was 0.63 (Pearson's $r$ ). The remaining six specimens had low correlation with the mean chronology and could not be positively cross-matched, among these was specimen H-1-2. Specimens H-1-4 and H-4-1 overlapped by five years (Figure 3). The 14RP1 site chronology could not be definitively dated with any of the regional oak master dating chronologies, and patterns in frost damaged rings in the site 


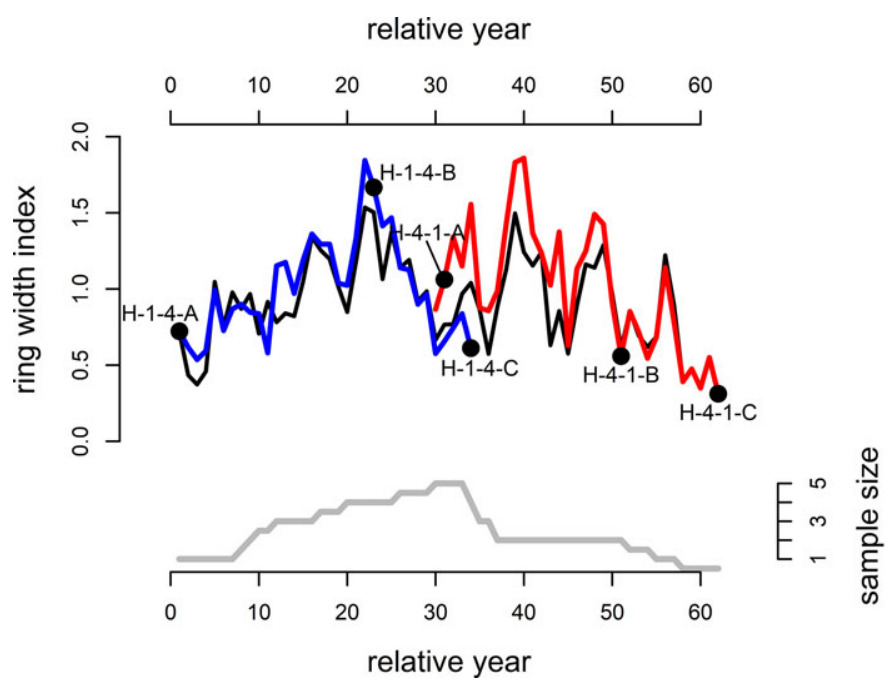

Figure 3 Top panel illustrates the mean ring-width index for 14RP1 (black line) and the ring-width indices for samples H-1-4 (blue line) and H-4-1 (red line). Points indicate the relative year of each ${ }^{14} \mathrm{C}$ sample from the two specimens in the floating ring-width chronology, labels correspond to the sample ID in Tables 1 and 2. Bottom panel shows the sample depth for each year in the mean chronology.

chronology lacked congruency with the regional record. Because of the low sample depth and limited overlap between H-1-4 and H-4-1 the site chronology for 14RP1 was considered tentative, in need of replication (e.g., additional samples) or independent validation.

\section{Radiocarbon Dating}

Table 2 summarizes the results of radiocarbon assays of the three support posts from 14RP1. A sequence of three ${ }^{14} \mathrm{C}$ measurements from post 2 in House 1 were wiggle-matched to IntCal20, and the best-match alignment position (Figure 4) resulted in high statistical agreement $(\mathrm{A} c o m b=117.6 \%)$. Independent wiggle matches from post 4 in House 1 and post 1 in House 4 placed them in sequential overlapping positions along the IntCal20 calibration curve consistent with their relative placement by tree-ring cross matching (Figure 5). The modeled dates for the floating ring series are in good agreement (Acomb $=109.7 \%$ ) despite the inclusion of sample $\mathrm{H}-4-1-\mathrm{A}$ with a wide ${ }^{14} \mathrm{C}$ measurement error due to low combusted sample mass $(0.06 \mathrm{mg})$. Due to the satisfactory agreement, this sample was retained in the date model.

The wiggle-match modeled date for the outermost ring of sample H-1-2 is between AD 1724 and AD 1774 (82.0\% probability) or 1844 and 1882 AD (13.4\% probability). The modelled outermost ring date for sample H-1-4 is between AD 1774 and AD 1794 (95.4\% probability) and the outmost ring for sample H-4-1 is between AD 1800 and AD 1820 (95.4\% probability).

\section{DISCUSSION AND CONCLUSIONS}

Since an unknown number of rings have been lost from the outsides of all the timbers, the exact year of death for the trees used in the construction of House 1 and 4 at 14RP1 cannot be determined. In situations where at least one sapwood ring is present, an estimate of the 


\begin{tabular}{|c|c|c|c|c|c|c|c|c|}
\hline \multicolumn{9}{|l|}{ Table 2} \\
\hline $\begin{array}{l}\text { Sample } \\
\text { ID }\end{array}$ & Lab no. & $\begin{array}{l}\text { Combusted } \\
\text { sample mass } \\
(\mathrm{mg})\end{array}$ & $\begin{array}{c}\mathrm{C} \\
\text { yield } \\
(\%)\end{array}$ & $\begin{array}{c}{ }^{14} \mathrm{C} \text { age } \\
\text { (years } \\
\text { BP) }\end{array}$ & $\delta^{13} \mathrm{C}$ & Calendar age ranges ( $\%$ probability) & $\begin{array}{l}\text { Modeled age } \\
\text { ranges ( } \% \text { proba- } \\
\text { bility) }\end{array}$ & $\begin{array}{c}\text { A } \\
(\%)\end{array}$ \\
\hline$\overline{\mathrm{H}-1-2-\mathrm{A}}$ & AA112013 & 0.42 & 39 & $222 \pm 32$ & -29 & $\begin{array}{l}1636-1690(37.8 \%) 1728-1809(48.7 \%) \\
1922-\text { present }(18.4 \%)\end{array}$ & $1645-1803(95.4 \%)$ & 121.3 \\
\hline H-1-2-B & AA112014 & 0.49 & 42 & $121 \pm 26$ & -27 & $\begin{array}{l}1680-1740(25.4 \%) 1752-1763(1.8 \%) \\
1800-1940(68.2 \%)\end{array}$ & $1680-1838(95.4 \%)$ & 103.4 \\
\hline $\mathrm{H}-1-2-\mathrm{C}$ & AA112015 & 0.44 & 40 & $177 \pm 25$ & -25 & $\begin{array}{l}1660-1695(18.6 \%) 1724-1812(52.3 \%) \\
1838-1878(5.0 \%) 1915 \text {-present }(19.5 \%)\end{array}$ & $\begin{array}{l}1724-1774(82.0 \%) \\
1844-1882(13.4 \%)\end{array}$ & 105.6 \\
\hline H-1-4-A & AA112016 & 0.43 & 32 & $164 \pm 37$ & -26 & $\begin{array}{c}1660-1711(17.4 \%) 1718-1823(41.7 \%) \\
1830-1894(17.9 \%) 1904-\text { present }(18.4 \%)\end{array}$ & $1744-1764(95.4 \%)$ & 128.9 \\
\hline H-1-4-B & AA112017 & 0.94 & 39 & $179 \pm 20$ & -25 & $\begin{array}{l}1660-1694(19.4 \%) \text { 1726-1810 (56.4\%) } \\
1918 \text {-present }(19.7 \%)\end{array}$ & $1765-1784(95.4 \%)$ & 120.1 \\
\hline $\mathrm{H}-1-4-\mathrm{C}$ & AA112018 & 1.18 & 42 & $223 \pm 20$ & -25 & $\begin{array}{l}1642-1680(45.3 \%) 1740-1753(3.8 \%) \\
1762-1800(44.7 \%) \quad 1940-\text { present }(1.7 \%)\end{array}$ & $1774-1794(95.4 \%)$ & 108.2 \\
\hline H-4-1-A & AA112019 & 0.06 & 22 & $280 \pm 110$ & -26 & $\begin{array}{l}1440-1710(63.6 \%) \\
1718-1882(18.5 \%) 1831-1894(6.8 \%) \\
1905 \text {-present }(6.6 \%)\end{array}$ & $1772-1792(95.4 \%)$ & 107.7 \\
\hline H-4-1-B & AA112020 & 1.06 & 38 & $207 \pm 25$ & -28 & $\begin{array}{l}1647-1686(29.4 \%) 1732-1805(56.1 \%) \\
1927-\text { present }(10.0 \%)\end{array}$ & $1790-1810(95.4 \%)$ & 76.6 \\
\hline $\mathrm{H}-4-1-\mathrm{C}$ & AA112021 & 1.38 & 40 & $125 \pm 20$ & -24 & $1682-1736(24.6 \%) \quad 1802-1936(70.8 \%)$ & $1800-1820(95.4 \%)$ & 90.8 \\
\hline
\end{tabular}




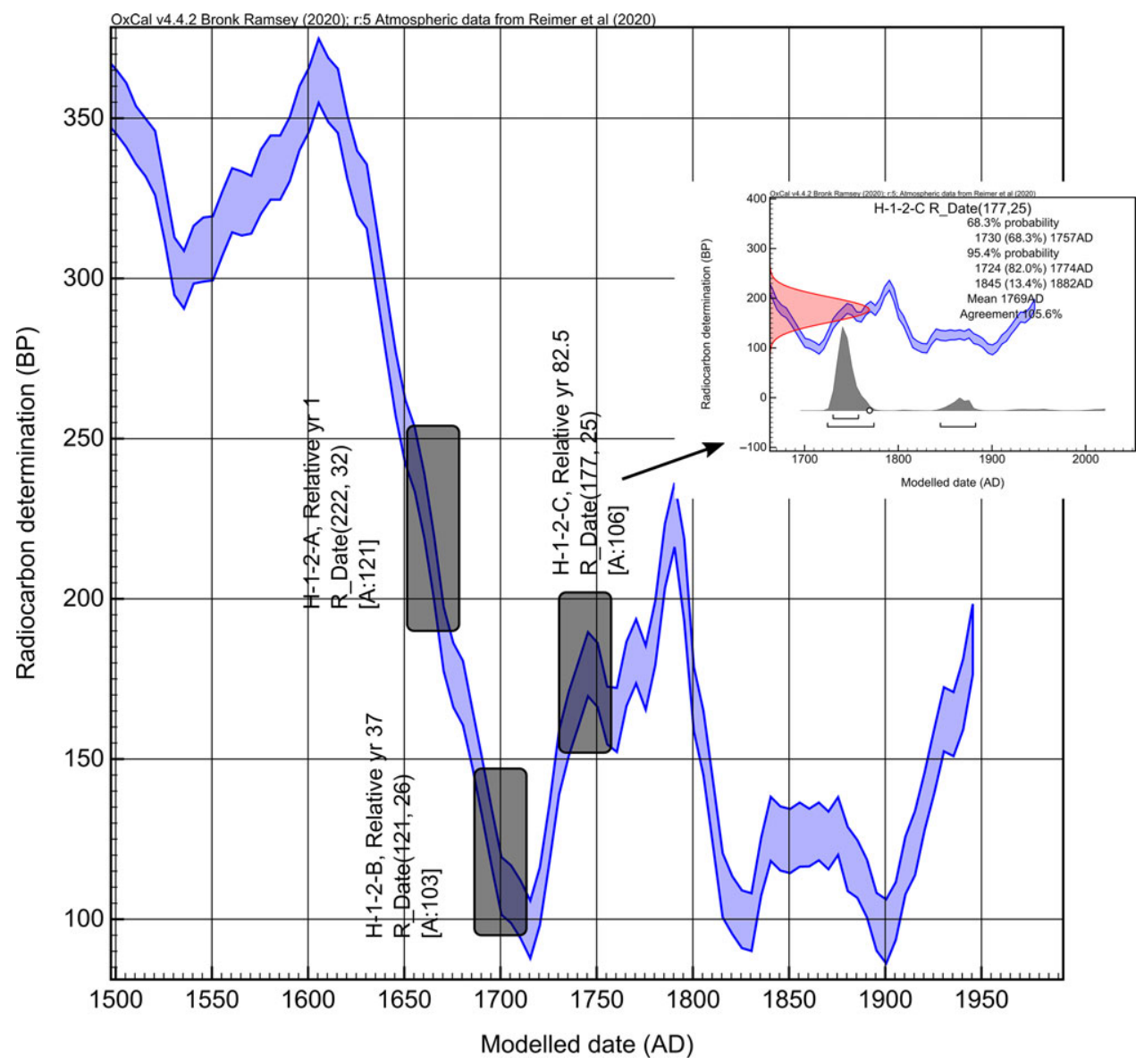

Figure 4 Measured ${ }^{14} \mathrm{C}$ content from post 2 in House 1 (H-1-2) at 14RP14 wiggle-mated (D_sequence) against IntCal13 (Reimer et al. 2013). ${ }^{14} \mathrm{C}$ ages and error are given in parentheses and the individual agreement of each date is given in brackets. The bars indicate the standard deviation ranges of ${ }^{14} \mathrm{C}$ age (vertical) and wiggle-match calibrated age (horizontal).

number of original sapwood rings can be made and a cutting date can be estimated within a margin of error. No sapwood rings are preserved on the specimens analyzed in the present study, and so radiocarbon age models for the outermost rings provide the earliest possible dates or terminus post quem (TPQ) for the construction of two earthlodges at 14RP1.

To improve the accuracy of the TPQ dates of tree procurement, data on typical sapwood rings counts from $Q$. macrocarpa are used in this study to derive a heuristic correction factor for the modeled ${ }^{14} \mathrm{C}$ ages. Twelve bur oak cross sections collected previously by the senior author (unpublished) from trees ranging in age from 45 to 123 years old growing in Republic County, Kansas contained between 5 to 23 years of sapwood with a mode of 13 years and mean of 15 years. In this sample, younger trees $(<60$ years) tend to have fewer sapwood rings $($ mean $=9$, range $=5-13$ ) than older trees (mean $=15$, range $=6-23$ ). These figures are comparable to ring count estimates based on $Q$. macropcarpa sapwood depths. Asbjornsen et al. (2007: Table 1) reported sapwood thickness ranging from $12.4 \mathrm{~mm}$ to $21.2 \mathrm{~mm}$ in a sample from the midwestern U.S. Dividing these figures by the mean width 


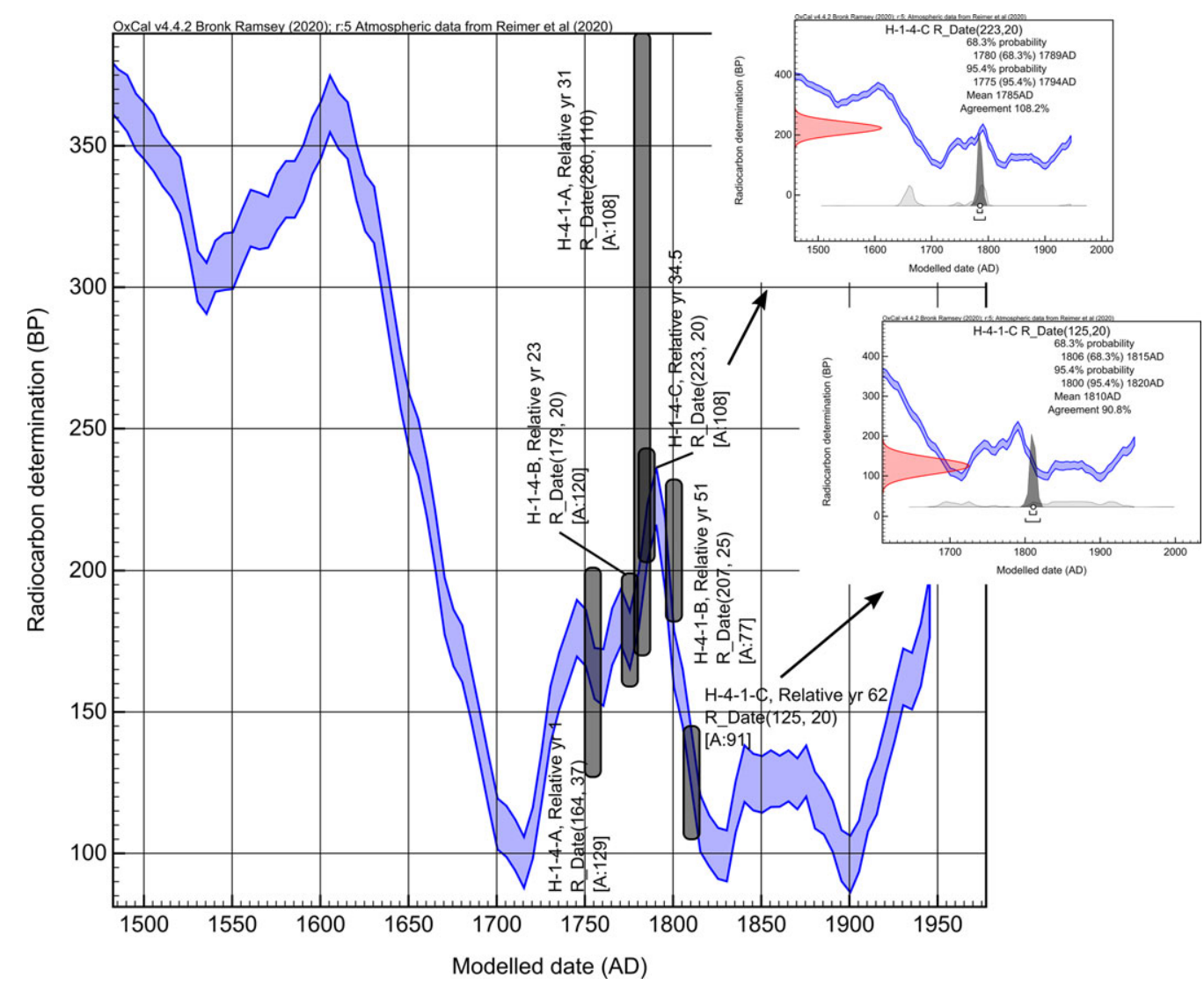

Figure 5 Measured ${ }^{14} \mathrm{C}$ content from post 4 in House 1 (H-1-4) and post 1 in House 4 (H-4-1) at 14RP14 wiggle-mated wiggle-matched (D_sequence) against IntCal13 (Reimer et al. 2013). ${ }^{14} \mathrm{C}$ ages and errors are given in parentheses and the individual agreement of each date is given in brackets. The bars indicate the standard deviation ranges of ${ }^{14} \mathrm{C}$ age (vertical) and wiggle-match calibrated age (horizontal).

of the five outermost rings of all eleven samples measured in this study, yields hypothetical sapwood ring counts from 8 to 13 years. Specimens H-1-4 and H-4-1 with 33 and 34 rings, are both from younger, smaller trees, and so a heuristic correction of 5 and 10 years is added to the upper and lower boundaries of the 95.4 percent probability date range respectively. For specimen H-1-2, with 83 rings, a wider correction factor is used: 5 and 25 years.

Prior to his study, the precise chronologies of Pawnee sites in the Republican valley were unsettled and inhibited the reconstruction of Kitkahahki history and explanations of social changes occurring on the southern frontier of the Pawnee homeland. Adair et al. (2007, 2008) discuss specific problems for Kitkahahki chronology and outlines three general historical phases for the contact period occupation of the Republican River valley. The first (ca. 1758-1777) represents the hypothetical time frame for the establishment of Pawnee villages in the area, and understanding this date is important for an analysis of the conditions of Kitkahahki ethnogenesis (Roper 2006). The second time-period (ca. 17771801) represents the main phase of Kitkahahki village growth in the area and has been 
understood to be the general time frame during which both 14RP1 and 25WT1 were occupied. The final phase (ca. 1806-1833) corresponds to a particularly tumultuous period in Kitkahahki history in which epidemics and intertribal war led to multiple population movements between the Republican and Loup valleys. The Kitkahahki encounter with the Pike expedition shows that they returned to $25 \mathrm{WT} 1$ by 1806 , but it is unclear if they were living at 14RP1 at the same time. The return lasted only three years, however, and the Kitkahahki were once again driven from the Republican valley in 1809. This hiatus lasted until the early 1820 s, at which time the Kitkahahki once again returned to the area and remained there until 1831. At that point, they left their Republican valley villages for the last time, and subsequently ceded all lands south of the Platte River in the Ellsworth treaty of 1833. Artifact assemblages indicative of 1820s habitation suggest that 25WT1 was the focus of occupation from 1806-1831, but the status of $14 \mathrm{RP} 1$ during this time period is unsettled.

The small number of calendar ages produced by this study cannot completely resolve all questions surrounding the chronology of Kitkahahki occupation at 14TRP1, but the high resolution of the dates obtained from building material from Houses 1 and 4 does enable comparison with the hypothetical chronology outlined above (Figure 6). The 95.4 percent probability range for the wiggle-matched date of specimen $\mathrm{H}-1-4$ places this post within the main phase of the Kitkahahki occupation of the Republican valley (1777-1801). Allowing for ring loss results in a corrected TPQ date between 1780 and 1804 . The $95.4 \%$ probability range for the wiggle-matched date of specimen H-4-1 overlaps the main phase of the Kitkahahki occupation by only two years (1800-1801) and falls mostly within the latter reoccupation (1806-1833). Factoring in sapwood ring loss results in a corrected TPQ date of 1805 to 1830 , and strongly indicates that beam 1 in House 4 was procured during one of the proposed reoccupations of the 14RP1 or 1806 and later.

The outermost rings of specimen H-1-2 probably dates within or prior to the earliest phase of Kitkahahki occupation of the Republican River valley. A lower probability region (13.4\% probability) of the modeled date for H-1-2 falls within the middle 19th century, an era unlikely to correspond with the true felling date because it is after when the Pawnee ceded land south of the Platte River, and encompasses the time period when the Pawnee relocated to a reservation in present day Oklahoma. Factoring in sapwood ring loss for specimen H-1-2 yields a probable TPQ date range of 1729 to 1799 . The sapwood corrected TPQ dates of specimens H-4-1 and H-2-1 overlap in time between 1780 and 1799 and may reflect contemporaneous tree procurement. Alternatively, H-2-1 may have been procured earlier, between the 1730s and 1770s and later reused in a new or rebuilt structure resulting in its ultimate deposition with specimen H-4-1. If the second scenario is correct, then the date for H-1-2 could correspond to the Kitkahahki - Chawi split in the middle 18th century and the first generation of permanent Kitkahahki residence in the Republican Valley.

If the felling date of the post sampled from House 4 is younger than those from House 1 as suggested by the modeled date ranges, then this would support scenarios involving multiple occupations of 14RP1 spanning the first decades of the 19th century. The persistence of residents at 14RP1 reflects an interesting divergence from the main trend of Pawnee settlement change at this time period which was generally characterized by the concentration of people in increasingly large, fortified, villages along the Platte and Loup Rivers. Compared to contemporaneous villages, 14RP1 (around 4 ha in area) would have been less than half the size of the average village (around 10 ha) occupied into the third decade of the 19th century. This could suggest that Kitkahahki were prioritizing different 


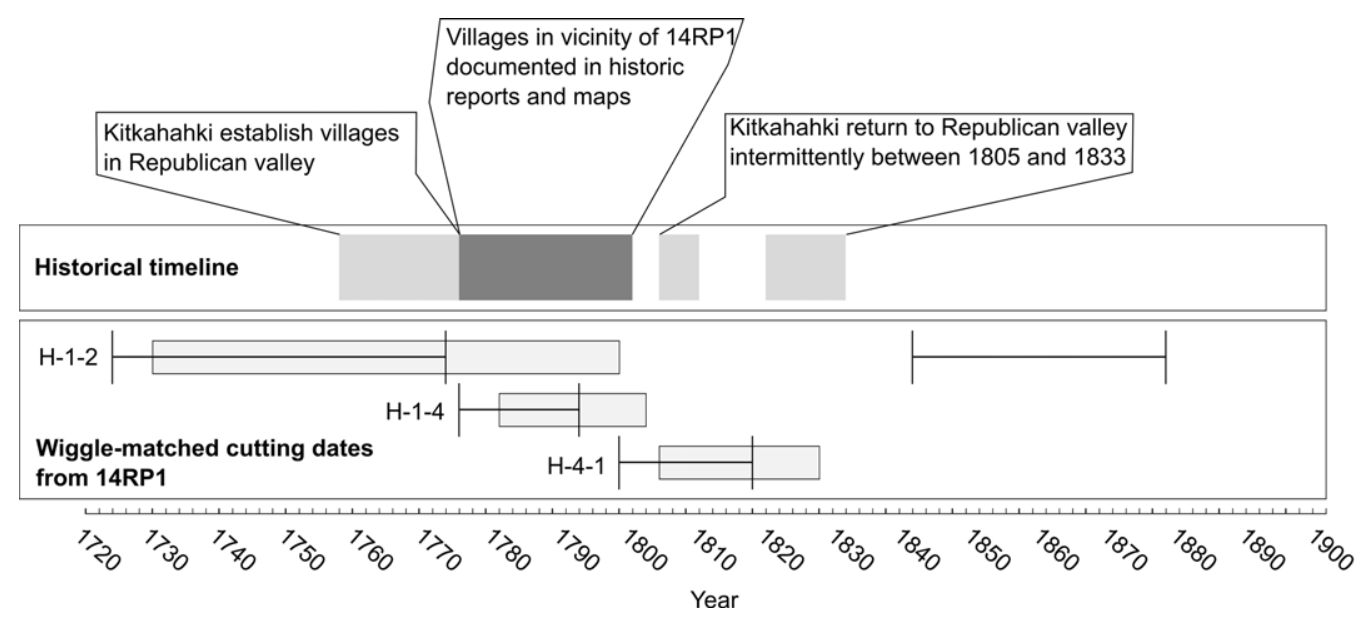

Figure 6 Comparison of the historical timeline (top panel) with the wiggle-matched ${ }^{14} \mathrm{C}$ cutting dates obtained in this study (bottom panel). Light gray bars in the historical timeline indicate conjectural time periods when it has been proposed that 14RP1 was occupied. The dark gray bars indicate the time period with convergent historical and archaeological evidence suggesting 14RP1 was almost certainly occupied. The brackets on the bottom panel illustrate the $95.4 \%$ probability interval of the modeled TPQ dates for each bur oak post analyzed in this study. Open boxes in the bottom panel indicate the TPQ date ranges corrected for sapwood ring loss.

factors in settlement decisions compared to the main body of Pawnee. The period after the 1770s was a particularly stressful time for the Pawnee as highlighted in recent oral histories and re-readings of Pawnee mythology (van de Logt 2016; Echo-Hawk 2018). Pan-Pawnee decision making and consensus building may have broken down during this time. Pawnee had a hereditary leadership system, but data from burials suggest that this period witnessed rapid change in the ways in which status was signaled. By incorporating more EuroAmerican trade items, status may have become more linked to wealth accrued by raiding, trade, and diplomacy, suggesting the authority of traditional leaders was being challenged (Callahan-Mims 2012). Echo-Hawk (2018: 36) in his reading of historical documents and retelling of family history suggests an economic and political motivation for the establishment of Kitkahahki villages in the Republican River valley. Specifically, Kitkahahki leaders seized an opportunity to hegemonize access to upper Republican hunting grounds and winter camps during the latter half of the 18th century after the last Apache communities withdrew from the area. Later in time, profitable raiding ventures along the new Santa Fe Trail would have provided a source of horses and other goods and may have motivated Kitkahahki to remain in the Republican valley despite danger from neighboring groups.

Our results show that trees continued to be procured for lodge construction into the 19th century, beyond the date conventionally assumed for the end of occupation at 14RP1. While two of the ring series subjected to wiggle-matching are relatively short $(<35$ rings), their placement in a floating chronology ameliorated potential accuracy problems from the use of short ring sequences (see Bayliss et al. 2017 and Hogg et al. 2017). The wigglematched ages of the rings are congruent with both their relative ages in the floating ring series and to the general historical context of the site. The dates agree with a historical scenario in which smaller groups of Kitkahahki continued to utilize the area despite larger scale settlement trends that concentrated populations in larger settlements in the core of the 
Pawnee homeland in Nebraska. In addition to the significance to Kitkahahki history, this treering radiocarbon study demonstrates an application of wiggle-matching to anchor floating tree-ring chronologies in a region where few tree-ring chronologies extend beyond living tree records.

\section{ACKNOWLEDGMENTS}

Funding for radiocarbon dating was provided by the Division of Archaeology, Biodiversity Institute at the University of Kansas. Dendrochronological analysis was funded by a generous private grant to the Pawnee Indian Village State Historic Site.

\section{SUPPLEMENTARY MATERIAL}

To view supplementary material for this article, please visit https://doi.org/10.1017/RDC. 2020.140

\section{REFERENCES}

Adair MJ, Roper DC, Hofman JL. 2008. Kitkahahki archaeology: a return to the Pawnee Indian village site. Kansas Preservation 30(5):13-17.

Adair MJ, Roper DC, Hofman JL. 2007. Kitkahahki archaeology: Investigations at the Pawnee Indian Village, 14RP1. Current Archaeology in Kansas 7(7).

Asbjornsen H, Tomer M, Gomez-Cardenas M, Brudvig L, Greenan C, Schilling K. 2007. Tree and stand transpiration in a Midwestern bur oak savanna after elm encroachment and restoration thinning. For. Ecol. Manage 247(1-3):209-219.

Asher BP. 2009. Kitkahahki chipped stone technologies: a comparative study.

Barry L. 1972. The beginning of the West: annals of the Kansas gateway to the American West, 15401854. Topeka: Kansas State Historical Society.

Bayliss A. 2009. Rolling out revolution: using radiocarbon dating in archaeology. Radiocarbon 51(1):123-147.

Bayliss A, Marshall P, Tyers C, Ramsey CB, Cook G, Freeman S, Griffiths S. 2017. Informing conservation: towards ${ }^{14} \mathrm{C}$ wiggle-matching of short tree-ring sequences from medieval buildings in England. Radiocarbon 59(3):985-1007.

Bayliss A, Ramsey CB, van der Plicht J, Whittle A. 2007. Bradshaw and Bayes: towards a timetable for the Neolithic. Cambridge Archaeological Journal 17(S1):1-28.

Beck M. 2020. Pawnee vessel function and ceramic persistence: Reconstructed vessels from the Burkett, Barcal, Linwood, Bellwood, and Horse Creek sites. Plains Anthropologist:1-24.

Bronk Ramsey C. 2009. Bayesian analysis of radiocarbon dates. Radiocarbon 51(1):337-360.

Bronk Ramsey C. 2000. Comment on "The use of Bayesian statistics for ${ }^{14} \mathrm{C}$ dates of chronologically ordered samples: a critical analysis". Radiocarbon 42(2):199-202.
Bronk Ramsey C, van der Plicht J, Weninger B. 2001.

"Wiggle matching" radiocarbon dates. Radiocarbon 43(2A):381-389.

Bunn A, Korpela M, Biondi F, Campelo F, Mérian P, Qeadan F, Zang C. 2017 Dplr: Dendrochronlogy program library in R. <https://CRAN.R-project. org/package $=\mathrm{d}$ plR $>$. Accessed 2019.

Callahan-Mims AF. 2012. Dynamic reconfiguration of pawnee social organization in the proto-historic and historic eras. https://digitalcommons.unl.edu/ anthrotheses/24: Anthropology Department, University of Nebraska, Lincoln.

Cook ER, Briffa K, Shiyatov S, Mazepa V. 1990. Tree-Ring standardization and growth-trend estimation. In: Cook ER, Kairiukstis LA, editors. Methods of dendrochronology: applications in the environmental sciences. Dordecht: Springer Media. p. 104-123.

Cook ER, Holmes RL. 1986. Users manual for program ARSTAN. In: Holmes RL, Adams RK, Fritts HC, editors. Tree-Ring chronologies of western North America: California, eastern Oregon and northern Great Basin. Tucson (AZ): Laboratory of Tree-Ring Research, University of Arizona. p. 50-65.

Echo-Hawk RC. 1992. Pawnee mortuary traditions. American Indian Culture and Research Journal 16(2):77-99.

Echo-Hawk W. 2018. Sea of grass: a family tale from the American heartland. Golden (CO): Fulcrum Publishing.

Fukuyo N, Yokoyama Y, Miyairi Y, Igarashi Y. 2019. AMS dating of potentially the oldest wooden sculptures in Japan from a Shinto shrine in Akita. Radiocarbon 61(5):1221-1228.

Galimberti M, Ramsey CB, Manning SW. 2004. Wiggle-Match dating of tree-ring sequences. Radiocarbon 46(2):917-224. 
Grange Jr RT. 1984. Dating Pawnee sites by the ceramic formula method. World Archaeology 15(3):274-293.

Gunnerson JH, Gunnerson DA. 1988. Ethnohistory of the High Plains. Denver: Colorado State Office, Bureau of Land Management.

Hill Jr ME, Trabert S. 2018. Reconsidering the Dismal River aspect: a review of current evidence for an Apachean (Ndee) cultural affiliation. Plains Anthropologist 63(247):198-222.

Hogg AG, McCormac F, Higham TF, Reimer PJ, Baillie MG, Palmer JG. 2002. High-Precision radiocarbon measurements of contemporaneous tree-ring dated wood from the British Isles and New Zealand: AD 1850-950. Radiocarbon 44(3):633-640.

Hogg A, Gumbley W, Boswijk G, Petchey F, Southon J, Anderson A, Roa T, Donaldson L. 2017. The first accurate and precise calendar dating of New Zealand Māori Pā, using Otāhau Pā as a case study. Journal of Archaeological Science: Reports 12:124-133.

Holmes RL. 1983. Computer-Assisted quality control in tree-ring dating and measurement. Tree-Ring Bulletin 43(1):69-78.

Houck L. 1909. The Spanish Regime in Missouri. Chicago: R. R. Donnelly and Sons Publishing Company.

Hudson L. 1993. Protohistoric Pawnee lithic economy. Plains Anthropologist 38(146): 265-278.

Hyde GE. 1988. The Pawnee Indians. Norman (OK): University of Oklahoma Press.

Johnson CM. 1998. The coalescent tradition. In: Wood WR, editor. Archaeology on the Great Plains. Lawrence (KS): University Press of Kansas. p. 308-344.

Keehner SP, Adair MJ. 2019. Modeling Kansas City Hopewell developments and regional social interactions: a multisite ceramic analysis and new AMS radiocarbon ages. Midcontinental Journal of Archaeology 44(1):2-41.

Kessler NV. 2009. Preliminary report on structural wood use at Pawnee Indian village (14RP1). Central Plains Archaeology 11(1):7-20.

Kim C, Lee J, Kang J, Song S, Yun M, Kim J. 2015. Radiocarbon dating of a pine tree (Pinus densiflora) from Yeongwol, Korea. Nuclear Instruments and Methods in Physics Research Section B: Beam Interactions with Materials and Atoms 361:332-334.

Kim Y, Son B, Imamura M, Park W. 2013. Tree-Ring dating and radiocarbon wiggle matching of Buddhist arhat statues at Heungkuksa temple in Namyangju, South Korea. Dendrochronologia 31(4):286-289.

Kinbacher KE. 2012. Indians and empires cultural change among the Omaha and Pawnee, from contact to 1808 . Great Plains Quarterly (Summer):207-221.
Lorentzen B, Manning SW, Cvikel D, Kahanov Y. 2014. High-Precision dating the Akko 1 shipwreck, Israel: wiggle-matching the life and death of a ship into the historical record. Journal of Archaeological Science 41:772-783.

Manning SW, Kromer B, Ramsey CB, Pearson CL, Talamo S, Trano N, Watkins JD. $2010 .{ }^{14} \mathrm{c}$ record and wiggle-match placement for the Anatolian (Gordion area) juniper tree-ring chronology $\sim 1729$ to 751 cal BC, and typical Aegean/Anatolian (growing season related) regional ${ }^{14} \mathrm{C}$ offset assessment. Radiocarbon 52(4):1571-1597.

Manning SW, Dee MW, Wild EM, Bronk Ramsey C, Bandy K, Creasman PP, Griggs CB, Pearson CL, Shortland AJ, Steier P. 2014. High-precision dendro- ${ }^{14} \mathrm{C}$ dating of two cedar wood sequences from First Intermediate Period and Middle Kingdom Egypt and a small regional climaterelated ${ }^{14} \mathrm{C}$ divergence. Journal of Archaeological Science 46:401-416.

Manning SW, Birch J, Conger MA, Dee MW, Griggs C, Hadden CS, Hogg AG, Bronk Ramsey C, Sanft S, Steier P. 2018. Radiocarbon re-dating of contact-era Iroquoian history in northeastern North America. Science Advances 4(12): eaav0280.

Manning SW, Birch J, Conger MA, Dee MW, Griggs C, Hadden CS. 2019. Contact-Era chronology building in Iroquoia: age estimates for Arendarhonon sites and implications for identifying Champlain's Cahiagué. American Antiquity 84(4):684-707.

Manning SW, Birch J, Conger MA, Sanft S. 2020. Resolving time among non-stratified shortduration contexts on a radiocarbon plateau: possibilities and challenges from the AD 1480 1630 example and Northeastern North America. Radiocarbon 2020. doi: 10.1017/RDC. 2020.51

Marshall P, Bayliss A, Farid S, Tyers C, Bronk Ramsey C, Cook G, Doğan T, Freeman SP, Ilkmen E, Knowles T. $2019 .{ }^{14} \mathrm{C}$ wigglematching of short tree-ring sequences from post-medieval buildings in England. Nuclear Instruments and Methods in Physics Research Section B: Beam Interactions with Materials and Atoms 438:218-226.

Munday FJ. 1927. Pike-Pawnee site: a review of the evidence of the case. Nebraska History Magazine 10(3):168-192.

Nasatir AP. 1952. Before Lewis and Clark: documents illustrating the history of Missouri. Lincoln: University of Nebraska Press.

Nishimoto H, Nakamura T, Takada H. 2010. Radiocarbon dating and wiggle matching of wooden poles forming circular structures in the 1st Millennium BC at the Mawaki archaeological site, central Japan. Nuclear Instruments and Methods in Physics Research 
Section B: Beam Interactions with Materials and Atoms 268(7-8):1026-1029.

Panyushkina IP, Leavitt SW, Mode WN. 2017. A 1400-year Bølling-Allerød tree-ring record from the US Great Lakes region. Tree-Ring Research 73(2):102-112.

Park W, Kim Y, Jeong A, Kim S, Oh J, Park S, Choi S, Park G, Seo J. 2010. Tree-ring dating and AMS wiggle-matching of wooden statues at Neunggasa temple in South Korea. Radiocarbon 52(3): 924-9-32.

Pearson CL, Ważny T, Kuniholm PI, Botić K, Durman A, Seufer K. 2014. Potential for a new multimillennial tree-ring chronology from subfossil Balkan river oaks. Radiocarbon 56(4): S51-9.

R Core Team. 2019. R: A language and environment for statistical computing. <https://www.Rproject.org/>.

Reimer PJ, Austin WE, Bard E, Bayliss A, Blackwell PG, Ramsey CB, Butzin M, Cheng H, Edwards RL, Friedrich M. 2020. The IntCal20 Northern Hemisphere radiocarbon age calibration curve (0-55 cal kBP). Radiocarbon 62(4):725-757. doi: 10.1017/RDC.2020.41.

Roberts RL. 1978. The archaeology of the Kansas Monument site: a study in historical archaeology on the Great Plains. Lawrence (KS): University of Kansas, Department of Anthropology.

Roper DC. 2012. New AMS radiocarbon dating results for Central Plains Tradition sites in Kansas and Nebraska. Plains Anthropologist 57(221):39-52.

Roper DC. 2006. The Pawnee in Kansas: ethnohistory and archaeology. In: Hoard RJ, Banks WE, editors. Kansas Archaeology. Lawrence (KS): University Press of Kansas. p. 233-247.

Roper DC. 1992. Documentary evidence for changes in protohistoric and early historic Pawnee hunting practices. Plains Anthropologist 37(141):353-366.

Roper DC, Pauls EP. 2005. What, where, and when is an earthlodge? In: Roper DC, Pauls EP, editors. Plains earthlodges: ethnographic and archaeological perspectives. Tuscaloosa (AL): University of Alabama Press. p. 1-31.

Roper DC, Adair MJ. 2011. Interpreting AMS radiocarbon age determinations from selected Central Plains Tradition sites. Plains Anthropologist 56(217):3-22.

Smith CS. 1949. Reports of summer field work. Plains Archaeological Conference News Letter 2(4):5-10.

Stahle DW. 1990. The tree-ring record of false spring in the southcentral USA.

Stambaugh MC, Bale A, Guyette RP. 2006 Brickyard conservation area, loess hills. <https://www.
ncdc.noaa.gov/paleo-search/?dataTypeId=18>. Accessed 2019.

Stambaugh MC. n.d. Tree-Ring dating of Pawnee houses along the republican river document. Report submitted to the Biodiversity Institute, University of Kansas, Lawrence.

Stambaugh MC, Guyette RP. 2009. Progress in constructing a long oak chronology from the central United States. Tree-Ring Research 65(2):147-157.

Steinke C. 2012. Leading the "Father": the Pawnee homeland, Courers de Bois, and the Villasur expedition of 1720. Great Plains Quarterly 32(1):43-62.

Turkon P, Manning SW, Griggs C, Ramírez MAS, Nelson BA, Padilla CT, Wild EM. 2018. Applications of dendrochronology in northwestern Mexico. Latin American Antiquity 29(1):102-121.

van de Logt M. 2016. "I was brought to life to save my people from starvation and from their enemies": Pahukatawa and the Pawnee trauma of genocide. American Indian Culture and Research Journal 40(3):23-46.

Vehik SC. 1989. Problems and potential in Plains Indian demography. Plains Anthropologist 34(124):115-125.

Wedel WR. 1936. An introduction to Pawnee archeology. Washington DC: Smithsonian Institution. Bureau of American Ethnology Bulletin 112.

Weltfish G. 1965. The lost universe. Lincoln (NE): University of Nebraska Press.

Wesler KW. 2001. Excavations at Wickliffe Mounds. Tuscaloosa (AL): University of Alabama Press.

White R. 1988. The roots of dependency: subsistence, environment, and social change among the Choctaws, Pawnees, and Navajos. Lincoln (NE): University of Nebraska Press.

Whittle A, Barclay A, Bayliss A, McFadyen L, Schulting R, Wysocki M. 2007. Building for the dead: events, processes and changing worldviews from the thirty-eighth to the thirty-fourth centuries cal. BC in southern Britain. Cambridge Archaeological Journal 17(S1):123-147.

Wishart DJ. 1979. The dispossession of the Pawnee. Annals of the Association of American Geographers 69(3):382-401.

Witty T, Jones B. 1966. Progress reports. Lawrence (KS): Manuscript on file, University of Kansas Biodiversity Institute and Natural History Museum, Archaeology Division.

Wood WR. 1996. The Missouri River Basin on the 1795 Soulard map: a cartographic landmark. Great Plains Quarterly (Summer):183-198. 